\title{
A Comparative Study of 80r and 240r Gamma Rays On Male Meiotic Chromosomes of Grasshopper Spathosternum Praciniferum
}

\author{
Pradip Kumar Sur ${ }^{1}$, Pranab Kumar Das ${ }^{2}$, Madhumita Basu ${ }^{3}$, \\ Sudipto Majumder ${ }^{4}$, Palash Talukder ${ }^{5}$. \\ Associate Prof. of Zoology (Retd. $)^{l}$, \\ Post Doc Research Scholar, \\ Research Scholar ${ }^{4,5}$, \\ Cytogenetics Laboratory, Dept. of Zoology, Kanchrapara College, Kanchrapara - 743145, West Bengal.
}

\begin{abstract}
Adult healthy males of short horned Indian grasshopper, Spathosternum praciniferum were irradiated with gamma rays with a dose of 80r and 240r while the untreated specimens served as control. The testes material of treated and untreated specimens fixed at different time intervals were subjected to squashflame-drying-iron-alum-haematoxylin technique. The control specimens showed very negligible frequency of aberrations in some meiotic stages while the treated specimens except only the spermatogonial metaphase, the Diplotene, Diakinesis, Metaphase - I, Anaphase -I, Metaphase -II, and Anaphase - II, yielded various types of aberrations. The comparative analysis of the data showed that maximum effect was at 16 hrs. i.e. somewhat time - dependent and the marker X-chromosome was more sensitive than autosomes and that Treatment-2 (240r) showed more aberrations (18.74\%) than Treatment - 1(80r) (16.20\%).
\end{abstract}

Key Words: Grasshopper, chromosome aberrations, gamma rays.

\section{Introduction}

The profound genotoxic effect of ionizing radiations on living tissues had been demonstrated first by Muller (1927) in Drosophila melanogaster. This paved the path to succeeding workers towards cytogenetic study of radiation induced chromosomal aberration in insects, as Carlson (1938, 1940, 1941a, 1941b, 1949), Carlson \& Harrington (1955), Ray-Choudhuri (1961), Manna and Majumdar (1962,1967,1968), Majumdar and Manna (1967), Kumaraswammy \& Rajasekarasetty (1975, 1976), Rajasekarasetty \& Kumarwaswamy (1979), Sur and Manna (1987), Sur (1998), Sur and Pandey (2004). Very recently, Song et al. (2008) mapped the chromosomal locations of two single-copy genes, Ser-1 and CI-13, in silkworm (Bombyx mori) by fluorescence in situ hybridization. Even, Dutrillauxet al. (2006) had reported a method for obtaining chromosome banding, from pachytene stage of the meiotic prophase in Coleopteran species, which will be of help in further cytogenetic studies by other workers.

In our previous studies Sur, Das, Thakur and Roy (2010), we assessed the effect of $\gamma$-rays in two species of grasshoppers, Oxya velox and Gesonula punctifrons, with a dose of 160r Sur; Das \& Das (2011) also studied the effect of X-ray (80r) on Oxya velox \& G. punctifrons. The present study is a similar investigation, but with a dose of 80r and240r on a single grasshopper species S. praciniferum. The effect was studied for four different time intervals, i.e. $0.25 \mathrm{hr}(15 \mathrm{~min}), 1 \mathrm{hr}, 16 \mathrm{hr}$ and $48 \mathrm{hr}$. Comparison with untreated species which served as control had also been evaluated here in.

\section{Materials And Method}

Indian species grasshoppers Spathosternum praciniferum were exposed to whole body $\gamma$-irradiation (80r) and (240r). Only healthy, adult males were considered in the study. After irradiation, the testes lobes of the species were dissected out in normal saline and tissues fixed in freshly prepared aceto-alcohol (acetic acid : alcohol $-1: 3(\mathrm{v} / \mathrm{v})$. The fixed testes were squashed in $45 \%$ acetic acid on albuminized slides, which were later kept overnight at 50\% alcohol. The cover slips detached automatically and the slides were stained with ironalum-hematoxylin. The slides were then studied under microscope. Data were scored by using 45 cells from spermatogonial metaphase, 450 cells each from diplotene, diakinesis, metaphase I, and 90 cells each from anaphase I, metaphase II and anaphase II stages (Table 3). A total of 136 individuals of species 1 (Table 1) and 135 individuals of species 2 (Table 2), were incorporated in the whole study, while the same number of individuals served as control. Various standard statistical tools as Standard Error (S.E.); Critical Difference (C.D.) at $5 \%$ and $1 \%$ levels; students' t-Test; chi-square $\left(\chi^{2}\right)$ analysis; Correlation coefficient (r-value); Analysis of Variance (ANOVA) or F-value of both Treatment 1 and Treatment 2; (Table 4) were used to analyze the data. 


\section{Spathosternum praciniferum (80r)}

\section{Results}

Control Series: A total of 6660 cells were studied for this control series. This series showed minimum frequency of aberrations, highest being $1.11 \%$ in Metaphase II and lowest being $0.00 \%$ for both Spermatogonial Metaphase and Anaphase II. The total percentage of aberrations for this series was $0.08 \%$ (Table 3 ).

Treatment1 Series:Similarly, 6660 cells were studied in this series. Some aberrations observed in this series are $19.33 \%$ in autosomes, $4.66 \%$ in sex chromosomes of Diplotene stage at $16 \mathrm{hr} ., 11.56 \%$ in autosomes and 5 in sex chromosomes of Metaphase I stage at $16 \mathrm{hr} ., 19.11 \%$ in autosomes and $1.11 \%$ in sex chromosomes of Metaphase I at $48 \mathrm{hr}$., etc. In all, there were 877 aberrations involving autosomes and 204 involving X chromosomes (Table 3) in all the meiotic stages studied. The total frequency of aberrations in this series is $16.23 \%$ (Table 3). Among all the meiotic stages scored, the highest aberration was obtained in Diplotene stage of Prophase I i.e. $22.06 \%$ followed by $19.72 \%$ of Anaphase I, $19.17 \%$ of Anaphase II, $16.94 \%$ of Metaphase II, $14.61 \%$ of Diakinesis of Prophase I, $11.67 \%$ of Spermatogonial Metaphase and $11.06 \%$ of Metaphase I (Table 3, Fig 1, Fig 3: PM 1-4). With respect to time, the frequency of aberration was $2.28 \%$ at $0.25 \mathrm{hr}$ (15 min), $7.09 \%$ at $1 \mathrm{hr}, 30.57 \%$ at $16 \mathrm{hr}$ and $24.98 \%$ at $48 \mathrm{hr}$. Therefore the aberration increased from $0.25 \mathrm{hr}$ to $16 \mathrm{hr}$, was highest at $16^{\text {th }} \mathrm{hr}$ and decreased thereafter (Table 3, Fig 2). Moreover, the X chromosome was found to be more affected than the autosomes.

Statistical analysis:

Chi square value, $\mathrm{T}$ value etc. are given in table $4 \mathrm{a}$. The ANOVA ( $\mathrm{F}$ value) is $9.56^{*}$ for this treatment species, which were significant at 5\% level (Table 4a).

\section{Spathosternum praciniferum (240r)}

Control Series:

In the same way, 6660 cells were studied in this series. Negligible aberrations were encountered here too. The maximum aberration observed in this series was $0.16 \%$ in Metaphase 1 and minimum was $0.00 \%$ for Spermatogonial Metaphase, Anaphase I and Anaphase II. Total percentage of aberrations was $0.12 \%$ (Table 3).

Treated Series:

Again, a total of 6660 meiotic cells were studied in this series. Some aberrations observed in this series are $11.33 \%$ in autosomes, $1.56 \%$ in sex chromosomes of Diakinesis stage at $16 \mathrm{hr} ., 15.33 \%$ in autosomes and $2.88 \%$ in sex chromosomes of Diplotene stage at $48 \mathrm{hr}$., $20.67 \%$ in autosomes and 6\% in sex chromosomes of Diplotene at $16 \mathrm{hr}$., etc. Here 1026 aberrations were observed with autosomes and 226 aberrations observed with $\mathrm{X}$ chromosomes (Table 3). Total aberration percentage was $18.80 \%$. Among all the meiotic stages recorded, the maximum frequency of aberration was $26.06 \%$, observed with Diplotene stage of Prophase I, followed by Anaphase I (23.06\%), Anaphase II (22.78\%), Metaphase II (21.67\%), Diakinesis of Prophase I (15.44\%), Metaphase I (13.17\%) and Spermatogonial Metaphase (11.67\%) (Table 3, Fig 1, Fig 4: PM 5-8).

Moreover, frequency of aberrations varied with respect to time. The maximum aberration was recorded at $16 \mathrm{hr}$ (35.14\%) post exposure. The other frequencies were $4.56 \%$ at $0.25 \mathrm{hr}, 9.67 \%$ at $1 \mathrm{hr}$ and $25.83 \%$ at $48 \mathrm{hr}$. Therefore the aberrations increased from $0.25 \mathrm{hr}$ to $16 \mathrm{hr}$, were highest at $16^{\text {th }} \mathrm{hr}$ and decreased thereafter (Table 3, Fig 2). Further the $\mathrm{X}$ chromosome was found to be more affected than the autosomes.

Statistical analysis:

The Chi square value.Tvalue are all highly significant and are given in table $4 \mathrm{~b}$.The ANOVA ( $\mathrm{F}$ value) for this species are $11.38 *$ and $9.56 *$ respectively, which were significant at $5 \%$ level.

Table 1: Number of male Spthosternum praciniferum (Treatment- 1) exposed to $\gamma$-rays (80r) and their testes fixed at different time intervals

\begin{tabular}{|l|l|l|l|}
\hline Fixation Time & Number of males irradiated & Number died & Number survived \\
\hline $0.25 \mathrm{hr}(15 \mathrm{~min})$ & 35 & 2 & 33 \\
\hline $1 \mathrm{hr}$ & 38 & 1 & 37 \\
\hline $16 \mathrm{hr}$ & 31 & 2 & 29 \\
\hline $48 \mathrm{hr}$ & 32 & 6 & 26 \\
\hline
\end{tabular}

Table 2: Number of male Spthosternum praciniferum (Treatment-2) exposed to $\gamma$-rays (240r) and their testes fixed at different time intervals

\begin{tabular}{|l|l|l|l|}
\hline Fixation Time & Number of males irradiated & Number died & Number survived \\
\hline $0.25 \mathrm{hr}(15 \mathrm{~min})$ & 34 & 1 & 33 \\
\hline $1 \mathrm{hr}$ & 36 & 3 & 33 \\
\hline $16 \mathrm{hr}$ & 35 & 4 & 31 \\
\hline $48 \mathrm{hr}$ & 30 & 7 & 23 \\
\hline
\end{tabular}


Table 3: A comparative study of the frequency of aberrations in autosomes and sex chromosomes (in parentheses) induced by Gamma -ray dose of 80r( Trt-1 ) and 240r ( Trt-2 ) in different meiotic stages of control and treated male grasshopper, Spathosternum praciniferum.

\begin{tabular}{|c|c|c|c|c|c|c|c|c|c|c|c|c|c|c|c|c|c|c|c|c|c|}
\hline \multirow[t]{3}{*}{$\begin{array}{c}\text { Fixation } \\
\text { Time }\end{array}$} & \multirow{2}{*}{\multicolumn{3}{|c|}{ SP.MTP }} & \multicolumn{6}{|c|}{ PROPHASE -I } & \multirow{2}{*}{\multicolumn{3}{|c|}{ METAPHASE -I }} & \multirow{2}{*}{\multicolumn{3}{|c|}{ ANAPHASE -I }} & \multirow{2}{*}{\multicolumn{3}{|c|}{ METAPHASE - II }} & \multirow{2}{*}{\multicolumn{3}{|c|}{ ANAPHASE - II }} \\
\hline & & & & \multicolumn{2}{|c|}{ DIPLOTENE } & \multicolumn{3}{|c|}{ DIAKNESIS } & \multirow[b]{2}{*}{ OT } & & & & & & & & & & & & \\
\hline & $\mathrm{NC}$ & $\mathrm{BR}$ & OI & NC & $\mathrm{BR}$ & OT & $\mathrm{NC}$ & $\mathrm{BR}$ & & $\mathrm{NC}$ & $\mathrm{BR}$ & OT & $\mathrm{NC}$ & $\mathrm{BR}$ & OT & $\mathrm{NC}$ & $\mathrm{BR}$ & OT & $\mathrm{NC}$ & $\mathrm{BR}$ & OT \\
\hline cove & 45 & $n(0)$ & (1) & 150 & (n) & $(n)$ & 450 & 00 & (n) & 150 & $0(0)$ & 000 & 00 & $1(0)$ & (a) & 0 & 1) & a & 00 & 0 & (n) \\
\hline IRT-1 & 45 & $1(0)$ & $0(0)$ & +450 & $t(1)$ & $1(0)$ & 450 & 1(1) & \begin{tabular}{|l|}
$2(0)$ \\
$2(0)$
\end{tabular} & 450 & $3(1)$ & $7(3)$ & 90 & $3(01)$ & $2(1)$ & 90 & $1(0)$ & \begin{tabular}{|l|}
$1(0)$ \\
$1(1)$ \\
\end{tabular} & 90 & 1(1) & $\begin{array}{l}401 \\
100\end{array}$ \\
\hline \multicolumn{22}{|l|}{$0.25 \mathrm{Hr}$} \\
\hline $\mathrm{CON}-2$ & 45 & $0(0)$ & $0,0\rangle$ & 450 & $1(0)$ & $0(0)$ & 450 & $0(0)$ & $0(0)$ & 450 & $1(0)$ & $0 ; 0\}$ & 90 & $0(0)$ & $0(0)$ & 90 & $1(0)$ & $\begin{array}{ll}0(0) \\
\end{array}$ & 90 & $0(0)$ & $0(0)$ \\
\hline TRT-2 & 45 & $2(0)$ & $0(0)$ & 450 & $7(2)$ & $3(1)$ & 450 & 1(0) & $5(1)$ & 450 & $6(1)$ & $8(2)$ & 90 & $7(2)$ & $9(3)$ & 90 & $2(1)$ & $2(0)$ & 90 & $4(1)$ & $5(1)$ \\
\hline CON-1 & 45 & $0(0)$ & $0(0)$ & 450 & $1(0)$ & $0(0)$ & 450 & $2(0)$ & $1(0)$ & 450 & $5(2)$ & $1(0)$ & 90 & $0(0)$ & $O(0)$ & 90 & $1(0)$ & $O(0)$ & 90 & $O(0)$ & $0(0)$ \\
\hline TRI-1 & 45 & $5(0)$ & $0(0)$ & 450 & $15(4)$ & $5(1)$ & 450 & $9(2)$ & 1(1) & 450 & $8(2)$ & $11(3)$ & 90 & $9(2)$ & $11(3)$ & 90 & $3(2)$ & $7(1)$ & 90 & $3(2)$ & $5(3)$ \\
\hline \multicolumn{22}{|l|}{$1 \mathrm{Hr}$} \\
\hline CON-2 & 45 & $O(0)$ & $0,0\}$ & 450 & $0(0)$ & $O(0)$ & 450 & $0(0)$ & $O(0)$ & 450 & $a(0)$ & $0(0)$ & 90 & $O(0)$ & $o(0)$ & 90 & $0(0)$ & $o(0)$ & 90 & $0(0)$ & $0(0)$ \\
\hline IRT-2 & 45 & $4(0)$ & $10\rangle$ & 450 & $22(7)$ & $9(2)$ & 450 & $10(1)$ & $15(3)$ & 450 & $17(3)$ & $82)$ & 90 & $2(+)$ & $5(2)$ & 90 & $4(1)$ & $8(5)$ & 90 & $9(0)$ & $8(3)$ \\
\hline CON-1 & 45 & $O(0)$ & $0(0)$ & 450 & $0(0)$ & $0(0)$ & 450 & $0(0)$ & $0(0)$ & 450 & $1(0)$ & $0(0)$ & 90 & $0(0)$ & $0(0)$ & 90 & $1(0)$ & \begin{tabular}{|l|}
$0(0)$ \\
\end{tabular} & 90 & $0(0)$ & $0(0)$ \\
\hline IRT-1 & 45 & $4(1)$ & $2(0)$ & 450 & $87(21)$ & $93(25)$ & 450 & $42(4)$ & $51(13)$ & 450 & $52(5)$ & $1 \$(3)$ & 90 & $7(2)$ & $9(5)$ & 90 & $10(5)$ & $9(5)$ & 90 & $12(6)$ & $10(6)$ \\
\hline \multicolumn{22}{|l|}{$16 \mathrm{Hr}$} \\
\hline $\mathrm{CON}-2$ & 45 & $O(0)$ & $0(0)$ & 450 & $1(0)$ & $0(0)$ & 450 & $1(0)$ & $0(0)$ & 450 & $1(0)$ & $0(0)$ & 90 & $0(0)$ & $0(0)$ & 90 & $1(0)$ & $p(0)$ & 90 & $O(0)$ & $0(0)$ \\
\hline IRT-2 & 45 & $7(0)$ & $1(0)$ & 450 & $93(27)$ & $103(29)$ & 450 & 510 & $69(7)$ & 450 & $68(3)$ & $22(5)$ & 90 & $15(4)$ & 10(3) & 90 & $22(2)$ & 50 & 90 & $8(4)$ & $5(4)$ \\
\hline CON-1 & 45 & $0(0)$ & $0(0)$ & 450 & $1(0)$ & $0(0)$ & 450 & $1(0)$ & $0(0)$ & 450 & $1(0)$ & $0(0)$ & 90 & $0(0)$ & $0(0)$ & 90 & $1(0)$ & \begin{tabular}{|l|}
$0(0)$ \\
\end{tabular} & 90 & $0(0)$ & $0(0)$ \\
\hline TRT-1 & 45 & $7(0)$ & $1(0)$ & 450 & $61(9)$ & $51(19)$ & 450 & $79(6)$ & $43(8)$ & 450 & $59(5)$ & $15(4)$ & 90 & $6(2)$ & $5(3)$ & 90 & $4(2)$ & \begin{tabular}{|l|}
$5(3)$ \\
\end{tabular} & 90 & $8(3)$ & 6(2) \\
\hline \multicolumn{22}{|l|}{$48 \mathrm{Hr}$} \\
\hline $\mathrm{CON}-2$ & 45 & $0(0)$ & $0(0)$ & 450 & $0(0)$ & $0(0)$ & 450 & $0(0)$ & $O(0)$ & 450 & $1(0)$ & $0(0)$ & 90 & $0(0)$ & $0(0)$ & 90 & $0(0)$ & $0(0)$ & 90 & $0(0)$ & $p(0)$ \\
\hline TRT-2 & 45 & $5(0)$ & $1(0)$ & 450 & $69(13)$ & $65(17)$ & 450 & $39(0)$ & $58(11)$ & 450 & $69(7)$ & $13(03)$ & 90 & $3(3)$ & $7(4)$ & 90 & $5(1)$ & 10(3) & 90 & $9(4)$ & $7(t)$ \\
\hline
\end{tabular}

Grand Total Control $1=21 / 6660=0.31 \%$

Grand Total Control $2=8 / 6660=0.12 \%$

Grand Total Treatment $2=1248 / 6660=18.73 \%$

N.B.: Hr. $=$ Hours, $\mathrm{NC}=$ No. of cells, $\mathrm{BR}=$ Break, $\mathrm{OT}=$ Other types, $\mathrm{CON}=$ Control, $\mathrm{TRT}=$ Treatment

Table - 4(a) Statistical analysis of data of Spathosternum praciniferum treated with 80r gamma ray ( Treat-1)

\begin{tabular}{|l|l|l|l|l|l|l|l|l|}
\hline $\begin{array}{l}\text { Aberration } \\
\text { Statistics }\end{array}$ & SP. MTP & DIPLOTENE & $\begin{array}{l}\text { DIAKINESI } \\
\text { S }\end{array}$ & $\begin{array}{l}\text { METAPHA } \\
\text { SE I }\end{array}$ & ANAPHASE I & $\begin{array}{l}\text { METAPHASE } \\
\text { II }\end{array}$ & $\begin{array}{l}\text { ANAPHASE } \\
\text { II }\end{array}$ & $\begin{array}{l}\text { POOLE } \\
\text { D }\end{array}$ \\
\hline $\begin{array}{l}\text { Control } \\
\text { S.E +/- }\end{array}$ & 1.788 & 1.643 & 1.816 & 3.271 & 1.732 & 1.342 & 1.789 & 4.321 \\
\hline $\begin{array}{l}\text { Treatment -1 } \\
\text { S.E. +/- }\end{array}$ & 1.821 & 24.981 & 16.124 & 9.142 & 2.394 & 2.61 & 3.18 & 26.421 \\
\hline $\begin{array}{l}\text { Treatment -1 } \\
\text { C.D. 5\% }\end{array}$ & 1.853 & 97.924 & 63.205 & 35.836 & 9.384 & 10.245 & 12.446 & 81.325 \\
\hline $\begin{array}{l}\text { Treatment-1 } \\
\text { C.D. } 1 \%\end{array}$ & 2.304 & 128.693 & 83.065 & 47.096 & 12.333 & 13.47 & 16.36 & 96.568 \\
\hline $\begin{array}{l}\text { Treatment-1 } \\
\text { t-values }\end{array}$ & 3.506 & $195.851^{* *}$ & $126.412^{* *}$ & $71.673^{* *}$ & $18.769^{* *}$ & $20.491^{* *}$ & $24.893^{* *}$ & $\begin{array}{l}85.269^{*} \\
*\end{array}$ \\
\hline $\begin{array}{l}\text { Treatment-1 } \\
\text { Chi-Square } \\
\text { values }\end{array}$ & 8.561 & $69.451^{* *}$ & $54.124^{* *}$ & $37.376^{* *}$ & $13.125^{*}$ & $16.392^{* *}$ & $18.933^{* *}$ & $59.587^{*}$ \\
\hline $\begin{array}{l}\text { Treatment }-1 \\
\text { r- values }\end{array}$ & 0.32 & $0.64^{*}$ & $0.84^{* *}$ & $0.79^{* *}$ & $0.54^{*}$ & $0.65^{*}$ & $0.71^{* *}$ & $*$ \\
\hline
\end{tabular}

\section{Overall Treatment $-1 \mathrm{~F}-$ Value $=9.56 * *$}

Table - 4(b Statistical analysis of data of Spathosternum praciniferum treated with 240r gamma ray (Treat-2))

\begin{tabular}{|l|l|l|l|l|l|l|l|l|}
\hline $\begin{array}{l}\text { Aberration } \\
\text { Statistics }\end{array}$ & SP. MTP & DIPLOTENE & DIAKINESIS & $\begin{array}{l}\text { METAPHAS } \\
\text { E I }\end{array}$ & ANAPHASE I & $\begin{array}{l}\text { METAPHAS } \\
\text { E II }\end{array}$ & $\begin{array}{l}\text { ANAPHASE } \\
\text { II }\end{array}$ & $\begin{array}{l}\text { POOLE } \\
\text { D }\end{array}$ \\
\hline $\begin{array}{l}\text { Control } \\
\text { S.E +/- }\end{array}$ & 1.447 & 1.411 & 1.433 & 2.379 & 1.047 & 1.456 & 1.647 & 2.031 \\
\hline $\begin{array}{l}\text { Treatment }-2 \\
\text { S.E. +/- }\end{array}$ & 1.786 & 27.226 & 15.115 & 10.938 & 2.577 & 3.259 & 2.341 & 16.324 \\
\hline $\begin{array}{l}\text { Treatment -2 } \\
\text { C.D. } 5 \%\end{array}$ & 1.753 & 106.723 & 59.249 & 42.876 & 10.938 & 12.751 & 9.117 & 52.364 \\
\hline $\begin{array}{l}\text { Treatment-2 } \\
\text { C.D. } 1 \%\end{array}$ & 2.819 & 140.257 & 77.866 & 56.348 & 13.278 & 16.758 & 12.061 & 69.527 \\
\hline
\end{tabular}




\begin{tabular}{|c|c|c|c|c|c|c|c|c|}
\hline $\begin{array}{l}\text { Treatment- } 2 \\
\mathrm{t}-\text { values }\end{array}$ & $4.383^{*}$ & $213.449 * *$ & $118.499 * *$ & $85.753 * *$ & $20.208 * *$ & $25.503 * *$ & $18.355^{* *}$ & $\begin{array}{l}92.358 * \\
*\end{array}$ \\
\hline $\begin{array}{l}\text { Treatment-2 } \\
\text { Chi-Square } \\
\text { values }\end{array}$ & $11.361^{*}$ & $112.682 * *$ & $43.752 * *$ & 39.981 ** & $14.562 * *$ & $15.369 * *$ & $12.381 *$ & $\begin{array}{l}71.892 * \\
*\end{array}$ \\
\hline $\begin{array}{l}\text { Treatment -2 } \\
\text { r- values }\end{array}$ & 0.43 & $0.67 * *$ & $0.87 * *$ & $0.81 * *$ & $0.62 * *$ & $0.71 * *$ & $0.80 * *$ & $0.93 * *$ \\
\hline
\end{tabular}

Overall Treatment $-2 \mathrm{~F}-$ Value $=11.38 * *$

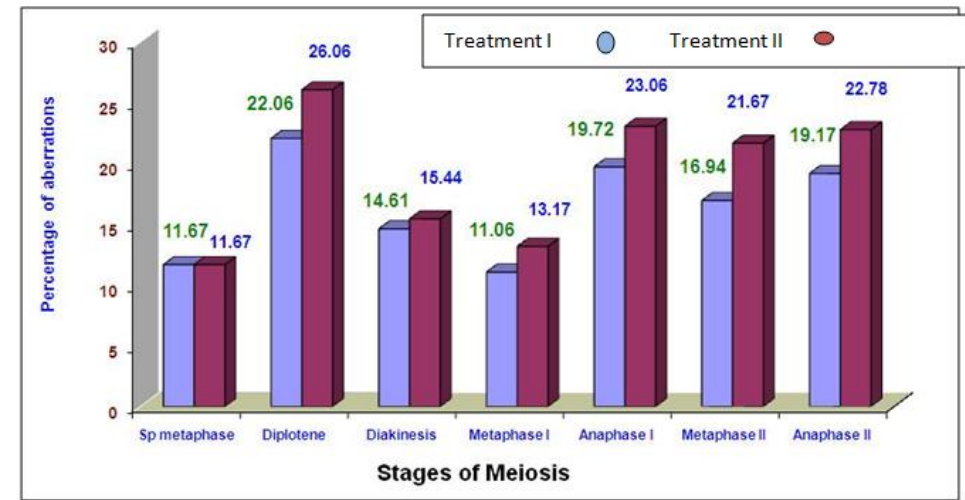

Sp metaphase $=$ spermatogonial metaphase, Treatment $1=$ Spathosternum praciniferum (Treated with 80r), Treatment 2= Spathosternum praciniferum (Treated with 240r).

Fig. 1: Bar diagram showing a comparative study between Treatments I (80r) and Treatment II (240r) against $\gamma$ ray dose w.r.t. of different meiotic stages.

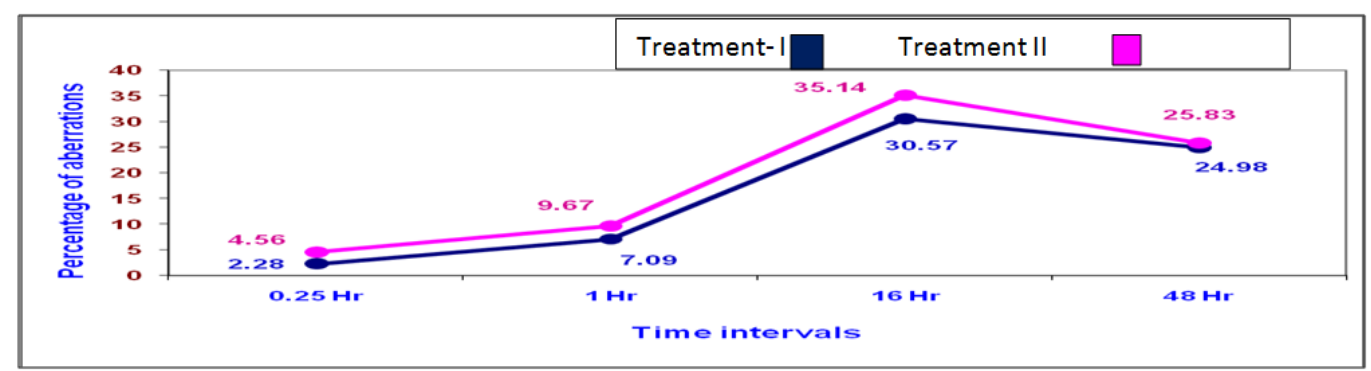

Treatment 1= Spathosternum praciniferum Treated with gamma (80r), Treatment $2=$ Spathosternum praciniferum Treated with gamma rays with (240r)

Fig. 2: Line-Diagram depicting chromosomal aberrations in Spathosternum praciniferum induced by $\gamma$-ray $(80 \mathrm{r})$ and (240r) w.r.t. time

\section{Discussion}

In series of experiments with grasshoppers by different workers, it was reported that the X chromosome was more affected to $\gamma$-irradiations than the autosomes (Manna and Mazumdar, 1962, 1967; Sur \& Manna 1987; Sur 1998, Sur and Pandey 2004, Sur, Das, Thakur and Roy 2010). Both spontaneous (Giles 1940) as well as $\gamma$ irradiated (Sax and Mather 1939) aberrations occur more frequently near the centromere than in the distal parts of the chromosome arms. Recently, experiments of Yoshimura et al. (2006) reported the results of zoo-blot hybridization of the genomic DNA from four species of grasshopper, Oxya hyla intricata, Oxya japonica japonica, Oxya chinensis formosana and Oxya. yezoensis. The results suggest that the two satellite DNA families found in their studies are species specific for O. hyla intricata. This result may also be helpful in localizing hot spots in the genome of Oxya against radiations. Also, Zainullin (1997) described the genotoxic effect of low intensity nuclear radiations in Drosophila melanogaster after the Chernobyl nuclear disaster in 1986 at Ukraine.

In our previous study, (Suret al 2010), reported that the most affected time interval $16 \mathrm{hr}(26.61 \%)$ in case of Oxya velox and (32.91\%) in case of Gesonula punctifrons).Sur et al. (2012 a \& b) 2012, (2015 a\& b) studied effects of different doses of gamma rays \& X-rays on fish, Oreochromis mossambicus, mice Mus musculus \& house musk shrew Suncus murinus. Sur ( 2012 ) had also reported some radio-protective phytomolecules extracted from Barlaria lupulina and subsequently patented with Govt. of India (2012). In the present study, similar results were obtained i.e. most affected time interval was $16 \mathrm{hr}(30.40 \%$ in case of Treatment I(80r) and 34.80\% in case of Treatment II (240r)(Table 3, Fig 2)). Moreover, previously, the most 
affected meiotic stage was Anaphase I (19.72\%) for Oxya velox and Metaphase II (24.72\%) for Gesonula punctifrons, where as in this study the most affected stage was Diplotene for both the species (11.23\% for Treatment I and $13.34 \%$ for Treatment II(Table 3, Fig 1)). Further we reported previously that Gesonula punctifrons was more sensitive than Oxya velox and the $\mathrm{X}$ chromosome was more affected to $\gamma$-irradiations than the autosomes. In the present study, in treatment 1 (80r) series aberration percent was 16.2 and in the treatment 2 series (240r) aberration percent was 18.73 and the sex chromosome was more sensitive than the autosomes.

\section{References}

[1]. Carlson, J.G. 1938. Some effect of x-irradiations on neuroblast chromosomes of the grasshopper, Crotophaga viridifasiata. Genetics, 23: 596-609.

[2]. Carlson, J.G. 1940. Immediate effects of 250r of $\mathrm{x}$-rays on the different stages of mitosis in neuroblasts of the grasshopper, Crotophaga viridifasiataJ. Morphol., 66: 11-23.

[3]. Carlson, J.G. 1941a. An analysis of X-rays induced single breaks in neuroblast chromosomes of the grasshopper, Crotophaga viridifasiataPoc. Nat. Acad. Sci. U.S., 27: 42-47.

[4]. Carlson, J.G. 1941b. Effect of X-irradiation on grasshopper chromosomes Cold Spring Habbor Symposia quant. Boil. 9: 104-112.

[5]. Carlson, J.G., Synder, M.L. and Hollaender, A. 1949. Relation of gamma-ray dosage rate to mitotic effect in the grasshopper neuroblast. J. Cellular Coma. Physiol., 33: 365-572.

[6]. Carlson, J.G. and Harrington, N.G. 1955. X-ray reduced "Stickiness" of chromosomes of the Chrotophaga neuroblast I relation to the dose and mitotic stage of treatment. Radiation Research. 2: 84-90.

[7]. Dutrillaux, A.M., Moulin, S. and Dutrillaux, B. 2006. Use of meiotic pachytene stage of spermatocytes for karyotypic studies in insects. Chromosome Res.14(50: 549-557.

[8]. Giles, N. 1940. The effects of fast neutrons on the chromosomes of Tradescantia. Proc. Nat. Acad. Sci. 26: 567-575.

[9]. Kumaraswammy, K.R. and Rajasekarasetty, M.R. 1975. Effect of gamma rays on the meiotic chromosomes of Poecilocera picta(Orthoptera). Egypt. Journal. 01 Geneics and Cytol., 4(2): 433-437.

[10]. Kumaraswammy, K.R. and Rajasekarasetty, M.R. 1976. Gamma-ray induced chromosomal aberrations in Poecilocera picta(Orthoptera). Ind. J.hered., 8(3/4): 11-12.

[11]. Manna, GK. And Mazumdar, S.C. 1962. The grasshopper X-chromosome as a indicator for X-ray induced chromosome breakage. Proc. Zool. Sco. 15(2): 103-110.

[12]. Manna, GK. And Mazumdar, S.C. 1967. On the qualitative aspects of X-ray induced sex-chromosome aberrations in the spermatocytes of grasshoppers. Nucleus, 10(2): 128-189.

[13]. Manna, GK. And Mazumder, S.C. 1968. Induced X-chromosomal aberration in the study of intra and inter specific sensitivity of grasshoppers. Internat. Seminar on chromosome- Its structure and function. August 11-13, Nucleus. 11(2): 197-209.

[14]. Mazumder, S.C. and Manna, GK. 1967. A quantitative study of X-ray induced chromosomal aberration in grasshopper. Nucleus. 10(2): 140-158.

[15]. Muller, H.J. 1927. Artificial transmutation of gene. Science, 66: 84-87.

[16]. Rajasekarasetty, M.R. and Kumaraswammy, K.R. 1979. Gamma ray induced bridges in the chromosomes of Poecilocera picta(Acrididae: Orthoptera). Nucleus. 22(1): 6-11

[17]. Ray-Choudhury, S.P. 1961. Induction of chromosome aberration in the spermatocytes of grasshopper. Nucleus. 4: 47-66.

[18]. Sax, K. and Mather, K. 1939. An X-ray analysis of progressive chromosome splitting.Jour. Genet. 37: 483-490.

[19]. Song, F., Chang, P., Zang, P., Yi, F., Ma, Y., Lu, C., Bano, Y. and Fujii, H. 2008. Chromosomal localization of silkworm (Bombyx mori) sericin gene 1 and chymotrypsin inhibitor 13 using fluorescence in situ hybridization. Sci. China. C. Life. Sci. 51(2): 133-139.

[20]. Sur, P.K. and Manna, G.K. 1987. A preliminary study of X-ray induced male meiotic chromosome aberration of grasshopper, Oxya velox. Perspective in cytology and genetics (End.- G.K. Manna and U. Sinha). 6(1989): 895-899.

[21]. Sur, P.K., Das, P.K., Thakur, A. and Roy, S. 2010. A comparative study of X-ray (160r) induced male meiotic chromosome aberrations in two short-horned grasshoppers, Oxya velox and Gesonula punctifrons. Proc. Zool. Soc. India. 9(1): 79-87.

[22]. Sur, P.K. 1998. A comparative study of X ray (100r) induced male meiotic chromosome aberration in two Indian grasshoppers, Oxya velox and Gesonula punctifrons. $11^{\text {th }}$ Biennial Conference on zoology, Zoological Society of Bangladesh, 1998, Dhaka University, Dhaka, Bangladesh (Accepted).

[23]. Sur, P. K. and Pandey, B.N. 2004. A comparative study of X-ray and chemical induced marker chromosome aberration in grasshoppers, Oxya velox and Gesonula punctifrons and their alterations by chemicals. Ph. D. Thesis, Magadh University, Bodh Gaya.

[24]. Ph.D. thesis of Dr. P.K.Sur, Magadh University Bodh Gaya 2004. Title "A Comparative Study of X-Ray and Chemical Induced Marker Chromosomes Aberrations in Grasshoppers , Oxya velox and Gesonula punctifrons and their alternations by Chemicals"

[25]. Sur PK, Das PK. Radio-protective and anti-clastogenic effects of Barleria lupulina Lindl. Extract against $\gamma$ (gamma)-ray (1.2 Gy) induced mitotic chromosomal aberrations of laboratory mice Mus musculus and its effect on fish tumour induced after $\gamma$ irradiation. Journal of Research in Biology (2012) 2(5): 439-447.

[26]. Sur PK ( 2012 ). Govt. of India Patent No. 639/KOL/2012, dated- $07 / 06 / 2012$

[27]. A Comparative Study Between Effect of Gamma Rays and X-Rays on Chromosomes of house Musk Shrew, Suncus murinus P.K.Das, P.K.Sur , and M.Basu. Fish , Environment and Human Health pages 125-137. Edited by B.N.Pandey,P.K.Sur et.al.2015.Narendra Publishing House, Delhi, WEB:www.nphindia.com

[28]. Yoshimura, A., Nakata, A., Kuro-o, M., Obara, Y., and Ando, Y., 2006. Molecular cytogenetic characterization and chromosomal distribution of the satellite DNA in the genome of Oxya hylaintricata (Orthoptera: Catantopidae). Cytogenet. Genome Res., 112(112): $160-165$

[29]. Zainnullin V.G. 1997. Genetic effects of chronic irradiation of low intensity. RadiatsBiolRadioecol., 37(4): 555-559. 

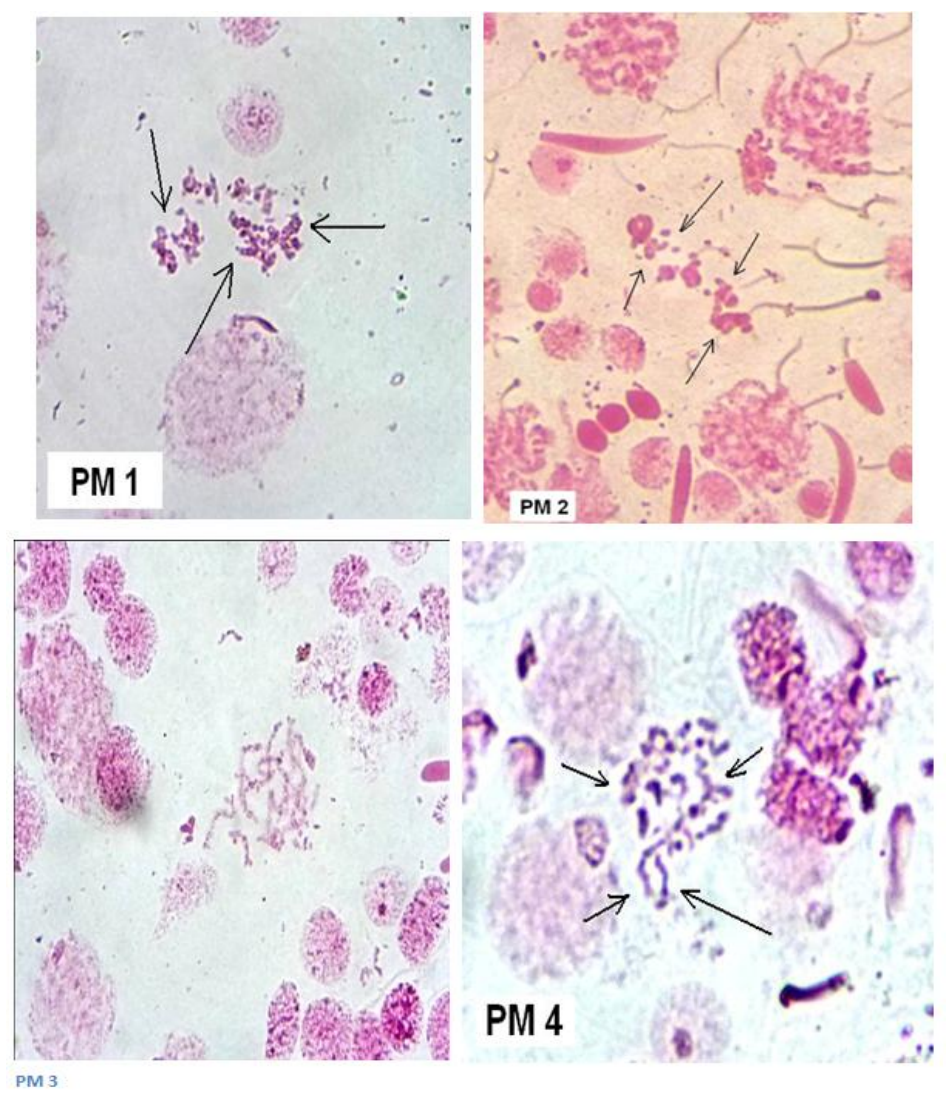

Photomicrographs (PM) showing different types of chromosomal aberrations in Spathosternum praciniferum in 80r gamma ray.

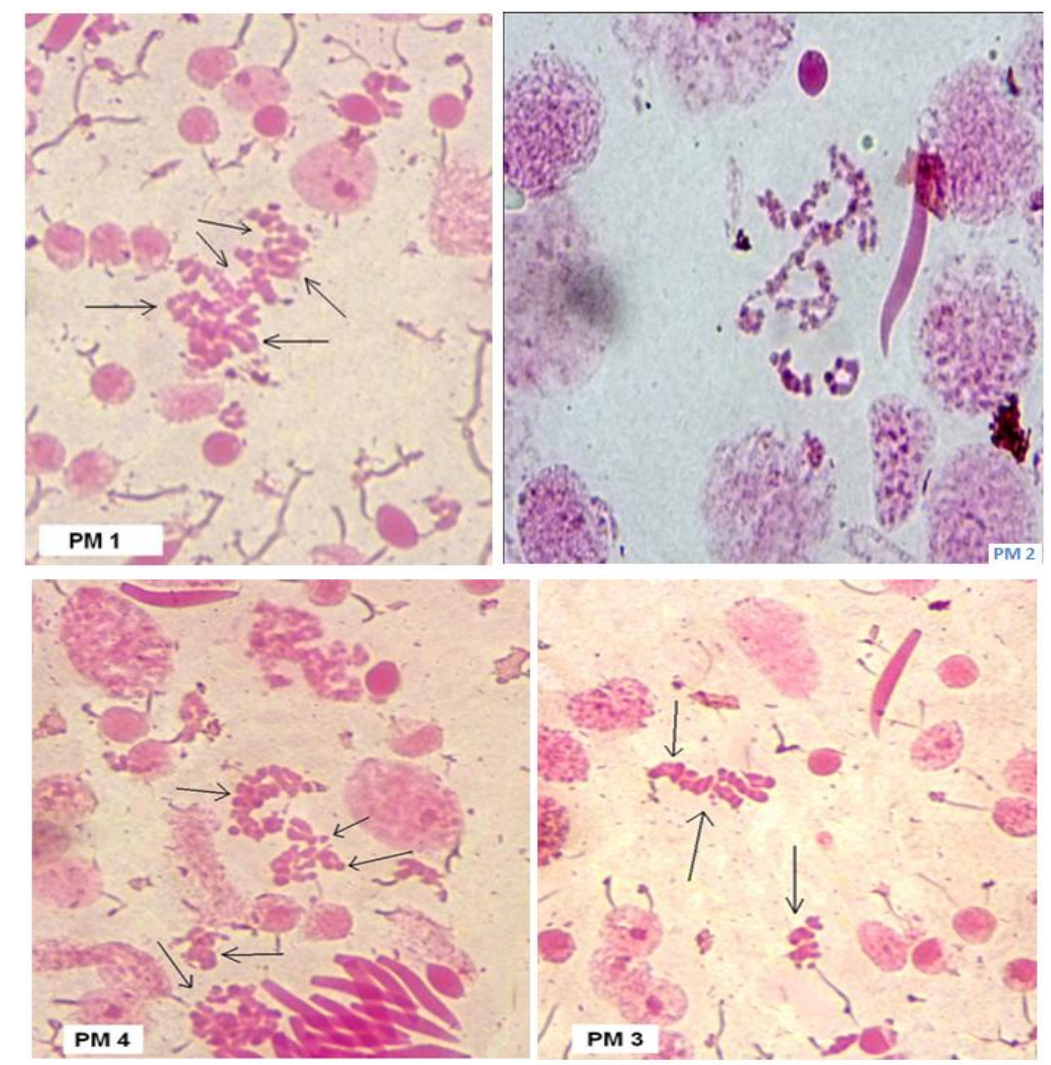

Photomicrographs (PM) showing different types of chromosomal aberrations in Spathosternum praciniferum in $240 \mathrm{r}$ gamma ray. 